\title{
Surface Water Quality in Relation to Land Cover in Agricultural Catchments (Liswarta River Basin Case Study)
}

\author{
Magdalena Matysik*, Damian Absalon, Marek Ruman
}

Faculty of Earth Sciences, University of Silesia, Będzińska 60, 41-200 Sosnowiec, Poland

Received: 6 May 2014

Accepted: 30 June 2014

\begin{abstract}
Agricultural activity results in water pollution from nitrogen and phosphorus compounds. Increased concentrations of nitrogen compounds pose a threat to animal and human health.

The purpose of this study was to determine the impact of agriculture in a catchment basin on the level of surface water pollution from biogenic compounds.

Spatial analysis of the land cover was conducted using GIS and was based on data from the Corine Land Cover databases.

The study results indicated that high concentrations of nitrogen and phosphorus compounds existed in the surface waters. In the surface water, high concentrations of biogenic compounds occurred in both primarily agricultural catchments and in urbanized drainage areas. Water may be regarded as eutrophicated or at high risk of eutrophication because the majority of the nitrate concentrations at the monitoring sites exceeded a limit of $10 \mathrm{mg} \cdot \mathrm{dm}^{-3} \mathrm{NO}_{3}^{2-}$.

Inadequate farming practices and poor sanitary conditions on farmsteads result in the leaching of biogenic substances into the water. To protect water from biogenic pollutants, it is necessary to adopt a new approach to fertilizer use and to improve the sanitary conditions of agricultural properties, which can be achieved by, among other things, the installation of drainage systems in rural areas. Our recommendations include the protection of river valleys as follows: by stopping deforestation, by preserving natural riparian vegetation, and by reducing the volume of intensified agricultural activity or introducing so-called "precision farming."
\end{abstract}

Keywords: water quality, water pollution, land cover, agriculture catchment, eutrophication

\section{Introduction}

Agricultural activity results in ground and surface water pollution from nitrogen and phosphorus compounds, which results from the excessive use of fertilizers containing these ingredients $[1,2]$. High concentrations of nitrogen compounds pose a threat to animal and human health and, in the

*e-mail: magdalena.matysik@us.edu.pl case of surface waters (lakes, seas, and rivers), these pollutants can lead to eutrophication, which disturbs the ecological balance of the aquatic environment [3-6].

Clean water is vital to human life and the proper functioning of natural ecosystems; as a result, the protection of water quality is one of the priorities identified by the European strategy for environmental protection. To protect water from nitrogen pollution, the EU member states are obliged to comply with the Nitrates Directive (91/676/EEC). 
The main aim of the said directive is to reduce agriculturally related nitrogen water pollution as well as to counteract possible future occurrences of this type of pollution. The maximum allowable concentration of nitrates in surface and ground water is $50 \mathrm{mg} \mathrm{NO} \mathrm{Nm}^{-3}$.

Studies of nitrogen and phosphorus pollution, as well as eutrophication problems, were carried out, among others, for surface water [3, 6-8] and for lakes [9-11]. The impact of agricultural catchments on water quality has also been described [12-15]. Haphazard waste water management is another factor contributing, along with agriculture, to decreasing water quality resources [16, 17]. Decreasing water and air quality contributes to a lower quality of life, which, in turn, has negative implications for public health, including children's health [18, 19].

The province of Silesia is known as a predominantly industrial region, yet agricultural land accounts for half of the area, and most of this agricultural land is located in the northern part of the province, including the catchment area of the Liswarta River. The region is characterized by relatively good environmental conditions, including soil conditions, that support agricultural production [20], which is conducted mainly in Lubliniec and Kluczbork counties. This location is favourable for the majority of cultivated plants: it has a long growing season of over 200 days per year and annual precipitation of $700 \mathrm{~mm}$. The main crops grown in Lubliniec County include rye, wheat, oats, cereal, barley, and potatoes, with an increasing contribution from maize. Animal husbandry is dominated primarily by pig farming. Kłobuck County was, until recently, a distinctly agricultural area that is currently focused on organic farming and the production of organic food. This entails particularly dynamic growth of the food-processing industry due to local agricultural production.

Agriculture is the main source of nitrates entering ground and surface water in Poland. Communities and households are also local and regional sources that contribute to the increased amount of nutrients in ground and surface water [21].
Farming systems involve the management of agricultural space and the related plant and animal production and processing, which can be described in ecological and economic terms. System differentiation is based on the degree to which farming activity is reliant on industrial means of production, mainly in terms of mineral fertilizer and pesticide use and their impact on the environment [22, 23]. Diffuse and point sources of nitrate pollution can be identified from most mixed farming systems in Poland. In general, only diffuse sources of nitrate pollution result from households that specialize in plant production.

The purpose of this study is to determine the impact of agricultural management in the Liswarta River catchment on biogenic pollution of surface water.

\section{Study Area}

The Liswarta catchment is located almost entirely in the province of Silesia, except for a small southwestern part of the basin, which is located in Opole Province (Fig. 1). The main part of the catchment basin is located in Kłobuck County, with only the northernmost part in Lubliniec County. The western part of the catchment is located in Oleski County, while its eastern section is located in Częstochowa County. The Liswarta catchment is home to 38 small villages with populations ranging from 300 to 500, and 78 large villages inhabited by 500-3,200 people. There is also one small town (Krzepice) with 4,500 inhabitants and one major town (over 9,000 inhabitants) named Kłobuck, with a population of 13,900 . The total population of the Liswarta basin is 112,197 , which corresponds to a population density of 72 people per $\mathrm{km}^{2}$ (based on an IMAGIS 2012 digital administrative map).

According to the physical-geographic division of Poland [24], the Liswarta catchment is located within the macro-region of the Woźnicko-Wieluńska Upland, with five identified mezzo-regions: the Woźnicki Threshold, the Liswarta Depression, the Herbski Threshold, the Krzepice Depression, and the Wieluńska Upland (Fig. 2).

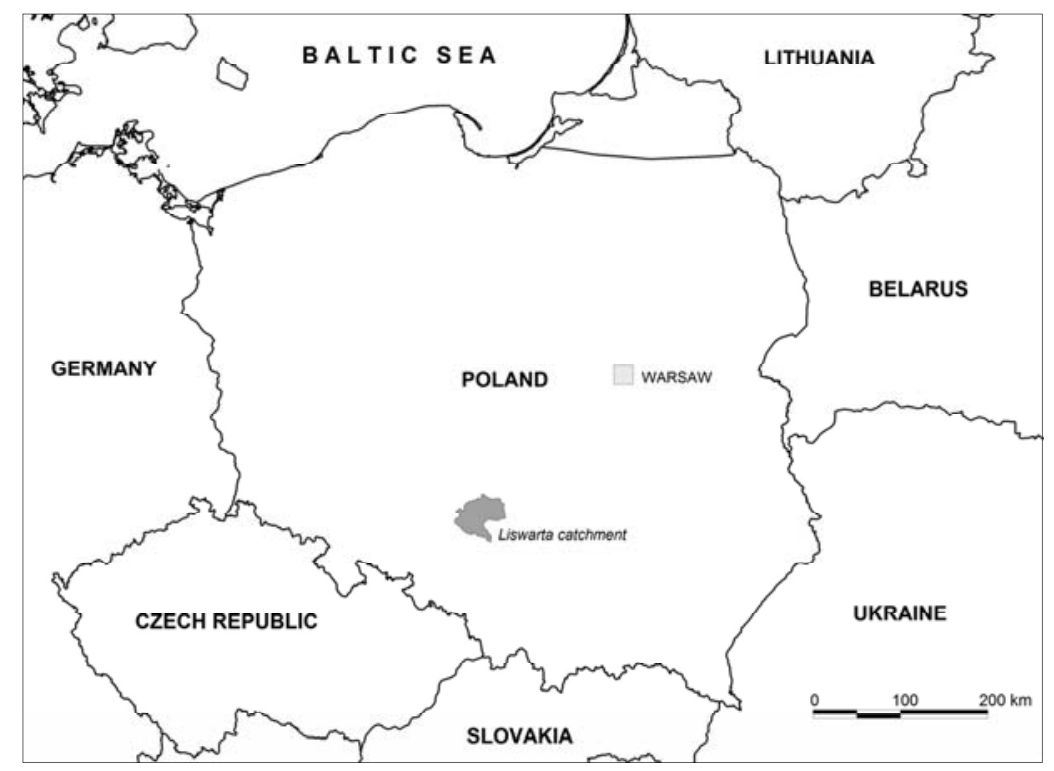

Fig. 1. Location of the study area. 


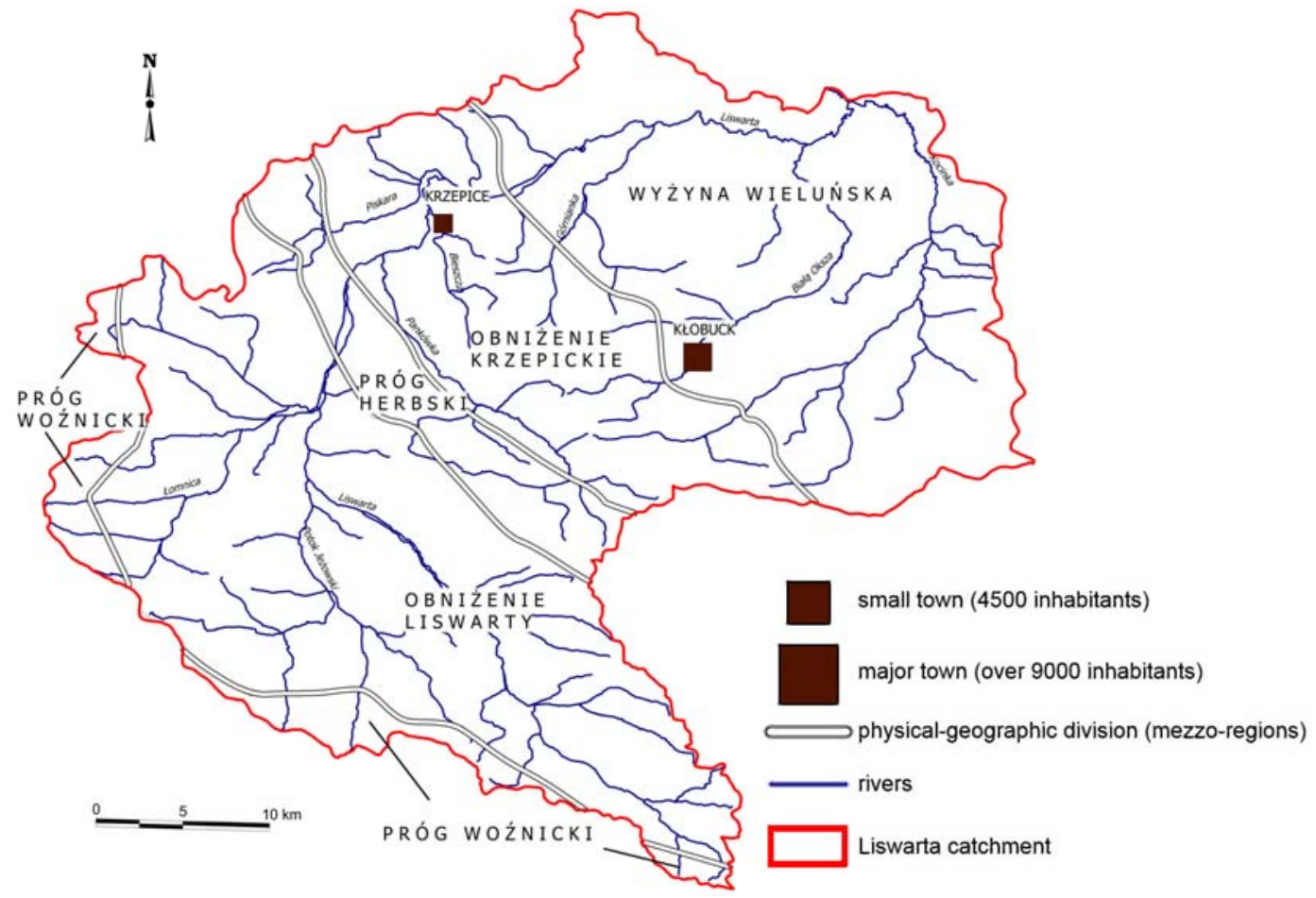

Fig. 2. Physical-geographic division of the study area.

The Liswarta is a left-bank tributary of the Warta River (the Odra River catchment) that is 93 kilometres long, with a catchment area of $1,577.7 \mathrm{~km}^{2}$.

The Liswarta catchment is a geologically and geomorphologically diverse area. The Woźnicko-Wieluńska Upland is built from Triassic and Jurassic rocks of varied strength, formed into limestone, sandstone, clay, and marl. Within the upland boundaries, one can distinguish hill ranges (thresholds) and a series of depressions. The area is elevated approximately $200 \mathrm{~m}$ above sea level in its northern part and approximately $380 \mathrm{~m}$ above sea level in the south.

The soil cover in the Liswarta catchment is similarly diversified. The parent rock of the local soils are mainly pre-Quaternary formations (sandstone, shale, limestone, and dolomite) and Quaternary material (sand, dust, loam, and loess soils), which cover the depressions and slopes of plateaus and ridges. The soils occurring in the area include podzols, alluvial soils, brown soils, rendzic soils, and black soils. Podzols are predominant here and occur mainly in the eastern part of the Liswarta Depression. Brown soils are found in the Woźnicki Threshold clays. In the river valleys, silt-peat and alluvial soils occur [20].

The Liswarta catchment is part of the KluczborkLubliniec hydrogeological region. There are three usable hydrogeological horizons: Quaternary, Jurassic, and Triassic. The Quaternary water-bearing horizon is predominant in the area. The groundwater table lies at a depth of several centimetres, only occasionally falling to several dozen meters below ground level in the area of Sieraków, Panoszów and Ciasna [25]. The well yield ranges between 1.20 and $64.60 \mathrm{~m}^{3} \cdot \mathrm{h}^{-1}$ [26].

The source of the Liswarta is located $315 \mathrm{~m}$ above sea level on the slope of the Woźnicki Threshold in the village of Babienica. The river network of the Liswarta catchment is relatively dense, except around the Woźnicki and Herbski Thresholds at the divide of the Warta, Liswarta and Mała Panew rivers, which are characterized by lower density.

The largest right-bank tributaries of the Liswarta are the Pańkówka, Bieszcza, Górnianka, Biała Oksza, and Kocinka. The left-bank tributaries include the Potok Jeżowski, Łomnica, and Piskara. The Kocinka is the longest tributary, with a length of $40.05 \mathrm{~km}$ and a drainage basin area of $259.9 \mathrm{~km}^{2}$.

\section{Materials and Methods}

The Polish CLC 90 database was updated in 2004. The resulting CLC2000 database contains information about land use as of 2000, as well as changes in land cover during the period from 1990-2000. Thirty-one forms of land use have been identified in Poland, compared with 44 identified for all of Europe. The database contains only surface objects. The smallest mapping area unit is 25 ha; the minimum width of delineations is $100 \mathrm{~m}$, which is the same as the accuracy required for boundary determination [27]. The reported data reliability for Poland is $85 \%$ [28, 29].

Spatial analysis of land cover in the Liswarta catchment was based on data from the CLC2000 and CLC2006 databases. Land cover analysis was conducted using GIS. Spatial analysis was performed for the entire Liswarta basin, including the catchments of its major tributaries as well as directly for the Liswarta catchment. Calculations of particular land cover surfaces (CLC delineations) were subsequently exported into Statistica software for statistical analysis. 
Water analyses were conducted using data obtained from the Regional Inspectorate of Environmental Protection in Katowice (polish acronym: WIOŚ). The surface water quality was monitored from 2000-10. The study focused on the following substances: ammonia, nitrites, nitrates, total nitrogen, phosphates and total phosphorus. After 2000 Liswarta's water quality was monitored in Boronów, Danków, Kule, Starokrzepice, and Zawady. Since 2010, the water quality tests for the Liswarta River were carried out solely in Boronów and Kule. After 2000, the water quality in the Biała Oksza River was monitored in Kłobuck, Łobodno, and at the confluence of the Biała Oksza and Liswarta rivers. The water quality of the Koninka River was monitored at the Trzebca site. Other tributaries that were monitored for water quality included Pańkówka, Potok Jeżowski, Górnianka, Bieszcza, and Piskara (Fig. 3).

\section{Results}

The predominant land cover in the Liswarta catchment is agricultural, covering an area of $955 \mathrm{~km}^{2}$ comprising mainly non-irrigated arable land (2.1.1), which covered $671.7 \mathrm{~km}^{2}$ (45\%) during from 2000 to 2006 . The second largest constituent within this agricultural land is cultivated land (2.4.2), covering $125.1 \mathrm{~km}^{2}(8 \%)$ during the study period. The third most common forms of land use are grasslands and pastures (2.3.1), covering $106 \mathrm{~km}^{2}$ (6.9\%). An area of $51 \mathrm{~km}^{2}(3.3 \%)$ was covered primarily by agricultural land with areas of natural vegetation (2.4.3). The proportion of orchards and plantations (2.2.2) in the Liswarta basin was low, at only $1.2 \mathrm{~km}^{2}(0.08 \%)$ from 2000 to 2006 .
The second largest types of cover within the Liswarta catchment were forest and semi-natural ecosystems, which stretched over $535 \mathrm{~km}^{2}(33.4 \%)$ in 2006, up from a level in 2000 of $533.5 \mathrm{~km}^{2}(31.91 \%)$. The largest area is occupied by coniferous forests (3.1.2), covering an area of $420 \mathrm{~km}^{2}$ $(27.2 \%)$ in 2000 , which increased to $431 \mathrm{~km}^{2}(27.9 \%)$ in 2006. Deciduous forests (3.1.1) covered an area of $50.7 \mathrm{~km}^{2}$ (3.3\%). Mixed forests (3.1.3) covered an area of $21.4 \mathrm{~km}^{2}$ $(1.4 \%)$ in 2000 and $23.5 \mathrm{~km}^{2}(1.5 \%)$ in 2006 . Forests and shrub lands undergoing transformation (3.2.4) in 2000 covered $41.5 \mathrm{~km}^{2}(2.7 \%)$, whereas in 2006 the percentage of this land cover decreased to $29.5 \mathrm{~km}^{2}(1.9 \%)$ (Table 1).

\section{Non-Agricultural Impacts on Water}

Practically all communities located within the Liswarta catchment have access to water supply systems. However, there is currently no coherent sewage disposal and treatment system operating within the area. Sewage management schemes are operated only in the towns of Kłobuck and Krzepice and in the communities of Wręczyca Wielka. In other communities, installations of rural drainage systems are set to begin or are in process. Therefore, in most places sewage is normally disposed of in isolated reservoirs or (often leaky) septic tanks, from where it is discarded onto the users' own land, into ditches, watercourses, or directly into the ground, thus resulting in surface and groundwater contamination. The exceptions include households that are equipped with household sewage treatment systems; however, their efficiency is largely dependent on applied technologies and strict adherence to proper use. The largest number of these sewage treatment systems is located in the community of Wręczyca. Household sewage treatment sys-
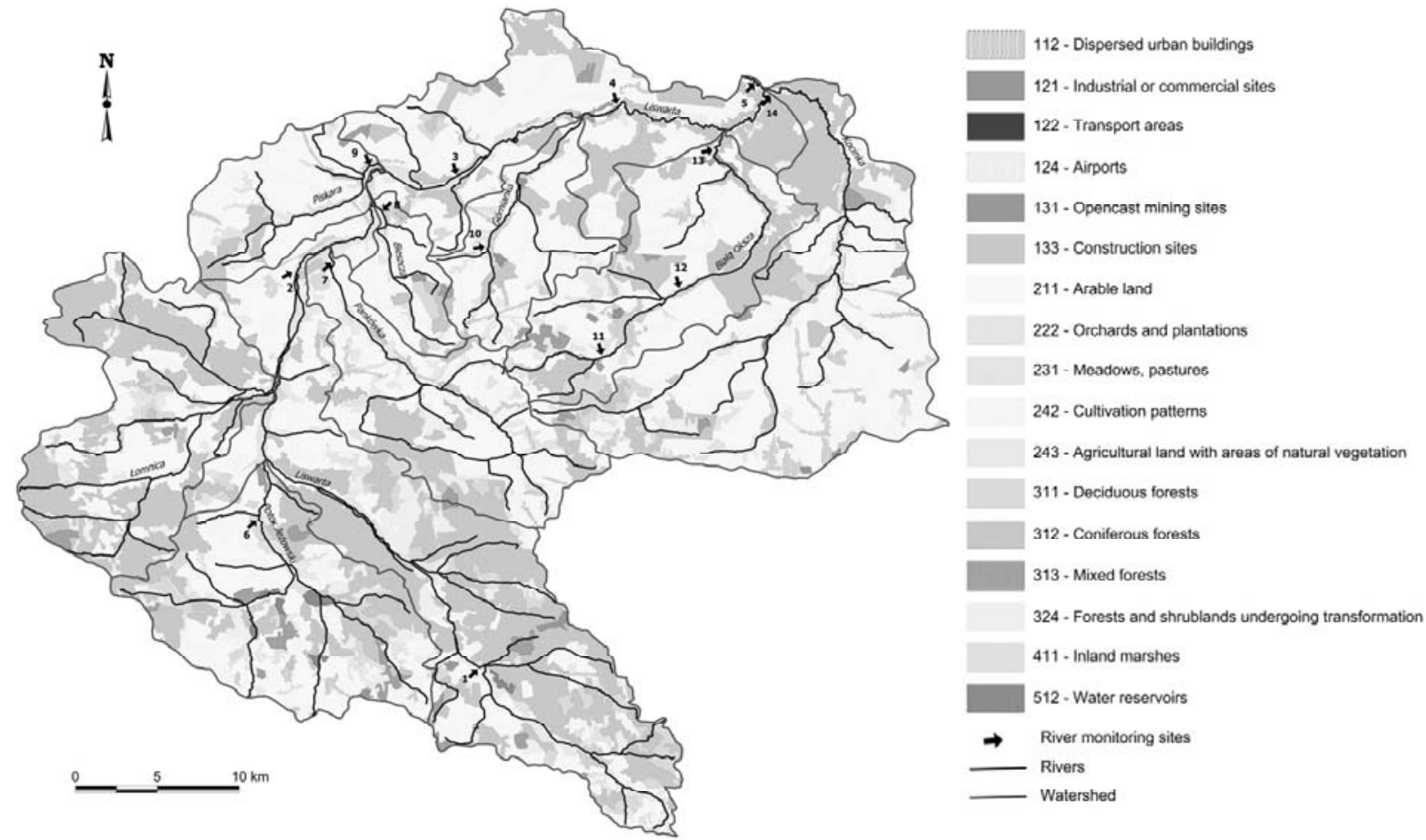

Fig. 3. The location of surface monitoring sites, including the land use patterns in the Liswarta catchment (numbered according to Figs. 4-9). 


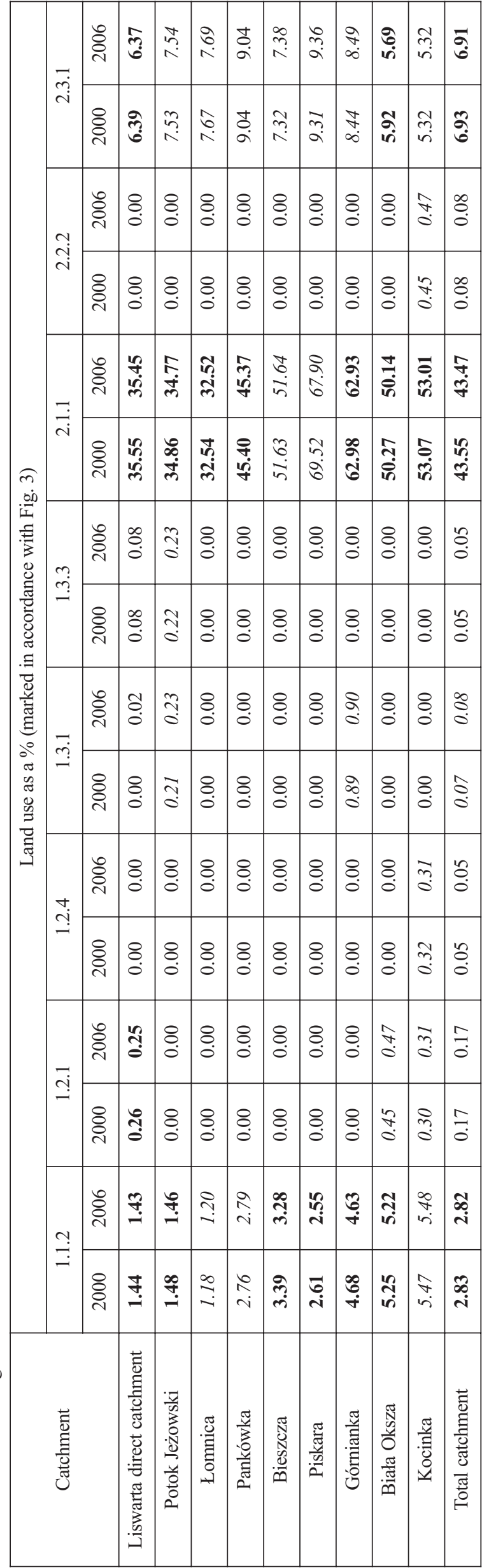

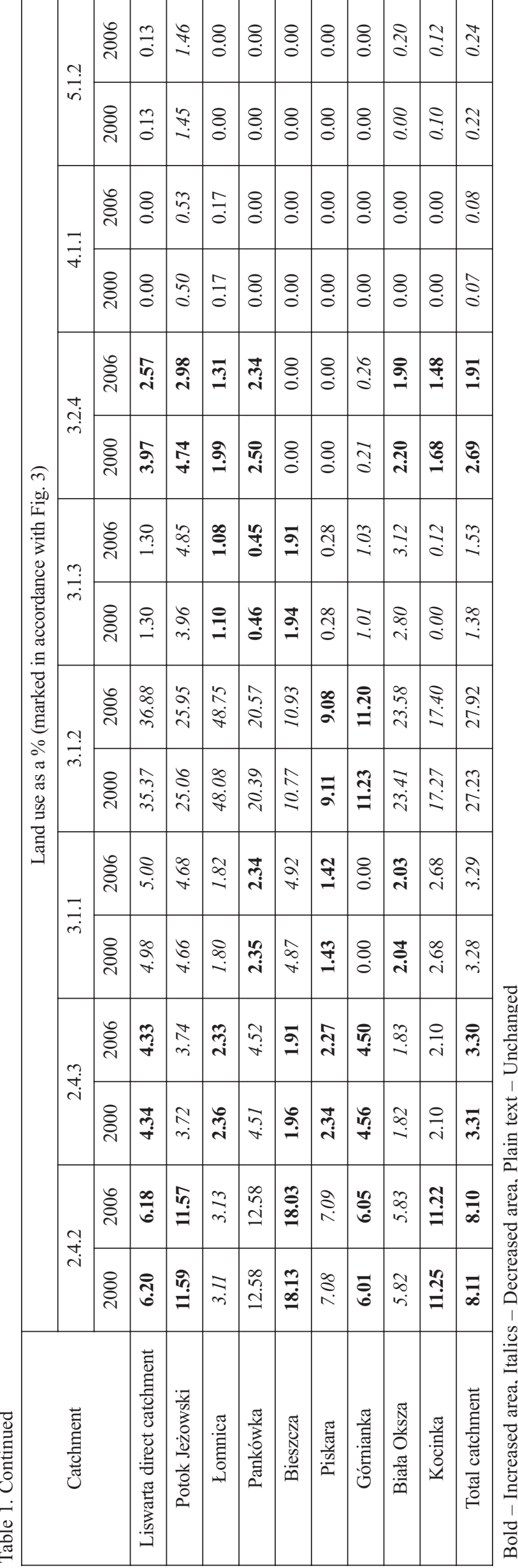


tems are characterized by a limited capacity, which does not exceed $5 \mathrm{~m}^{3} \cdot 24 \mathrm{~h}^{-1}$.

There are 13 professional sewage treatment plants located in the Liswarta catchment area and most of them are classified as biological-mechanical treatment systems. The largest number of treatment plants (5) is operated in the Biała Oksza catchment area in the community of Kłobuck. In terms of the Kocinka catchment, there are three treatment plants located in the communities of Częstochowa, Wręczyca Wielka, and Mykanów. There are two plants (located in the community of Opatów) within the Górnianka catchment and two more in the Potok Jeżowski catchment (in the communities of Ciasna and Kochanowice). Only one sewage treatment plant is located in the community of Popów, in the Liswarta River catchment.

\section{Surface Water Quality}

The chemical composition of surface water in the Liswarta catchment is affected by natural and anthropogenic factors. Eutrophication is regarded as one of the most serious threats to surface and coastal water quality $[30,31]$. Under the current legislation, eutrophication is defined as the process during which water becomes enriched with biogenic substances including, in particular, nitrogen and phosphorus compounds, which stimulate the growth of algae and other higher forms of life, thereby leading to a disturbance in the water regime and the subsequent deterioration of water quality [32]. There is also a risk of secondary water contamination that can be caused by substances known to be toxic to higher organisms, which are produced during the anaerobic digestion of phytoplankton $[6,14,33]$.

The highest average concentration of ammonia from 2000-10 (1.741 $\left.\mathrm{mg} \cdot \mathrm{dm}^{-3}\right)$ was reported for the Biała Oksza River at the Łobodno site. The average concentration of ammonia reported at the Kłobuck monitoring site was $0.473 \mathrm{mg} \cdot \mathrm{dm}^{-3}$, while the figure recorded at the mouth of the Biała Oksza River was $0.508 \mathrm{mg} \cdot \mathrm{dm}^{-3}$ (Fig. 4).

The lowest average concentration of ammonia (0.09 $\mathrm{mg} \cdot \mathrm{dm}^{-3}$ ) was recorded in the Liswarta River at
Starokrzepice. A higher average concentration of 0.530 $\mathrm{mg} \cdot \mathrm{dm}^{-3}$ from $2000-10$ was reported at the LiswartaBoronów site above Starokrzepice. When measured below Starokrzepice, the average concentration of ammonia in Danków was $0.455 \mathrm{mg} \cdot \mathrm{dm}^{-3}$, that in Zawady was 0.182 $\mathrm{mg} \cdot \mathrm{dm}^{-3}$, and that at the final site (Kule) was $0.260 \mathrm{mg} \cdot \mathrm{dm}^{-3}$. Among the Liswarta tributaries, the lowest average concentration from 2000-10 was reported in the Piskara River, of $0.132 \mathrm{mg} \cdot \mathrm{dm}^{-3}$.

The systematic growth of ammonia concentrations was reported for the Biała Oksza River in Łobodno in 2000, when the average annual $\mathrm{NH}_{4}^{+}$concentration was 0.303 $\mathrm{mg} \cdot \mathrm{dm}^{-3}$, which reached the highest level of $3.74 \mathrm{mg} \cdot \mathrm{dm}^{-3}$ in 2007.

The highest average nitrite concentration levels from 2000-10 were reported in Łobodno (Biała Oksza River), at a level of $0.613 \mathrm{mg} \cdot \mathrm{dm}^{-3}$. At monitoring sites on the Biała Oksza River above (in Kłobuck) and below Łobodno (at the river's mouth), the average nitrite concentration levels were 0.136 and $0.153 \mathrm{mg} \cdot \mathrm{dm}^{-3}$, respectively. The lowest average nitrite concentrations, below $0.1 \mathrm{mg} \cdot \mathrm{dm}^{-3}$ from $2000-10$, were recorded at the following sites: Boronów, Starokrzepice, Kule (on the Liswarta), Trzebca (on the Kocinka), at the mouth of the Pankówka, at Ciasna on Potok Jeżowski, and at the mouth of the Piskara. At the other two sites, Liswarta-Danków and Górnianka-Opatów, the average concentrations remained below $2 \mathrm{mg} \cdot \mathrm{dm}^{-3}$. A considerable decrease in the average annual nitrite concentration levels was observed at Łobodno on the Biała Oksza River (Fig. 5).

The highest average nitrate concentrations from 200010 were observed at the following sites: Opatów on the Górnianka River $\left(32.8 \mathrm{mg} \cdot \mathrm{dm}^{-3}\right)$, the mouth of the Piskara River $\left(31.8 \mathrm{mg} \cdot \mathrm{dm}^{-3}\right)$, Krzepice on the Bieszcza River $\left(23.2 \mathrm{mg} \cdot \mathrm{dm}^{-3}\right)$, and Lobodno on the Biała Oksza River $\left(22.7 \mathrm{mg} \cdot \mathrm{dm}^{-3}\right)$. The lowest average nitrate concentrations were reported in Kłobuck on the Biała Oksza River (10.0 $\left.\mathrm{mg} \cdot \mathrm{dm}^{-3}\right)$, Ciasna on the Potok Jeżowski River (11.2 $\left.\mathrm{mg} \cdot \mathrm{dm}^{-3}\right)$, Starokrzepice on the Liswarta River, and Trzebca on the Kocinka River $\left(13.4 \mathrm{mg} \cdot \mathrm{dm}^{-3}\right)$. The average nitrate concentrations that were recorded at other sites remained below $20 \mathrm{mg} \cdot \mathrm{dm}^{-3}$ (Fig. 6).

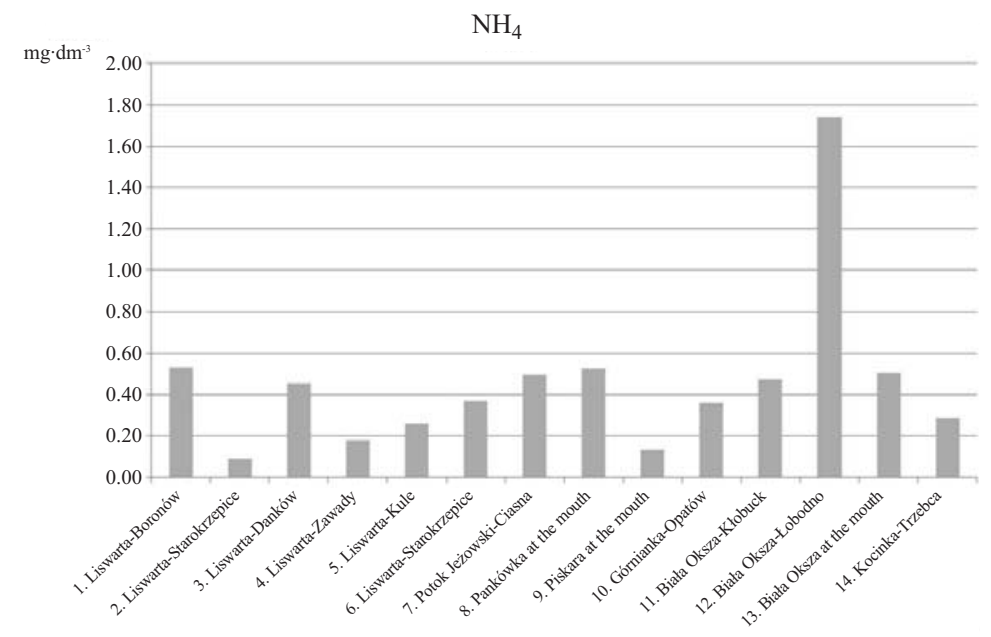

Fig. 4. The average concentration of $\mathrm{NH}_{4}^{+}$at surface water monitoring sites from 2000-10. 


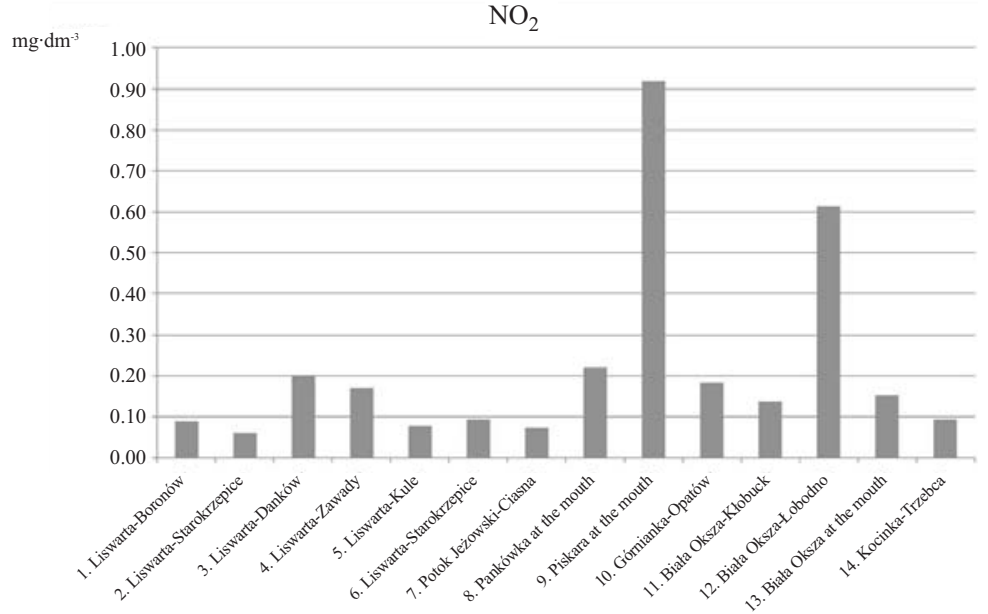

Fig. 5. The average concentration of $\mathrm{NO}_{2}^{-}$at surface water monitoring sites from 2000-10.

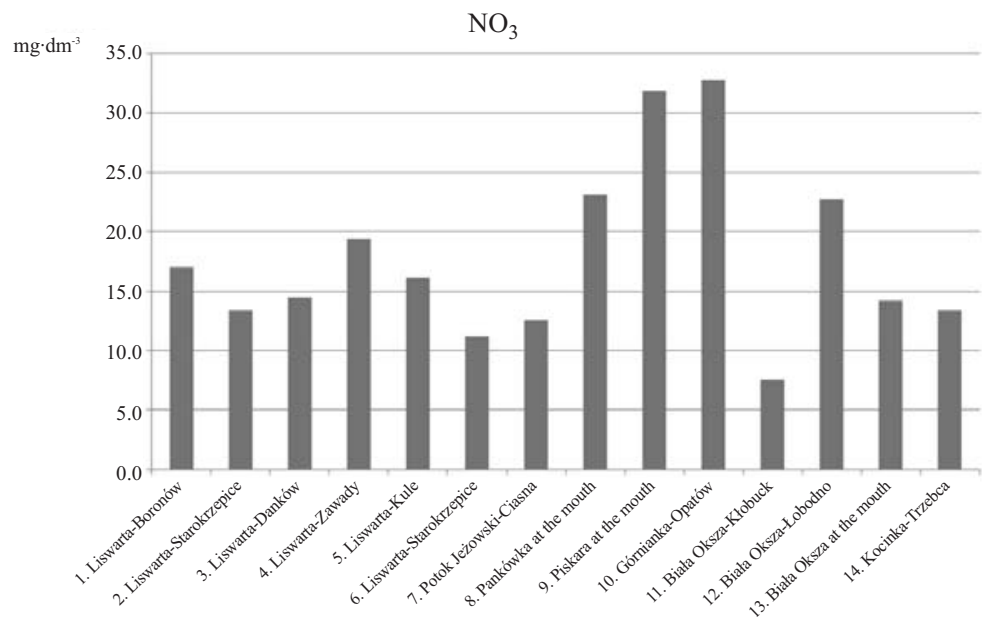

Fig. 6. The average concentration of $\mathrm{NO}_{3}^{-}$at surface water monitoring sites from 2000-10.

The highest total nitrogen concentrations from 2000-10 were found at Opatów on the Górnianka River (8.84 $\left.\mathrm{mg} \cdot \mathrm{dm}^{-3}\right)$, Łobodno on the Biała Oksza River $\left(8.21 \mathrm{mg} \cdot \mathrm{dm}^{-3}\right)$, and at the mouth of the Piskara River $\left(8.08 \mathrm{mg} \cdot \mathrm{dm}^{-3}\right)$. The lowest average concentrations occurred at Starokrzepice on the Liswarta River at $3.81 \mathrm{mg} \cdot \mathrm{dm}^{-3}$. The average concentrations reported at other sites ranged between $4.4 \mathrm{mg}$
(Kłobuck on the Biała Oksza River) and $5.92 \mathrm{mg} \cdot \mathrm{dm}^{-3}$ (Boronów on the Liswarta River) (Fig. 7).

The highest average phosphate concentration from 2000-10 was observed in Łobodno (on the Biała Oksza River) $-0.983 \mathrm{mg} \cdot \mathrm{dm}^{-3}$. At monitoring sites on the Biała Oksza River, above (in Kłobuck) and below Łobodno (at the confluence of the Biała Oksza and Liswarta rivers), the

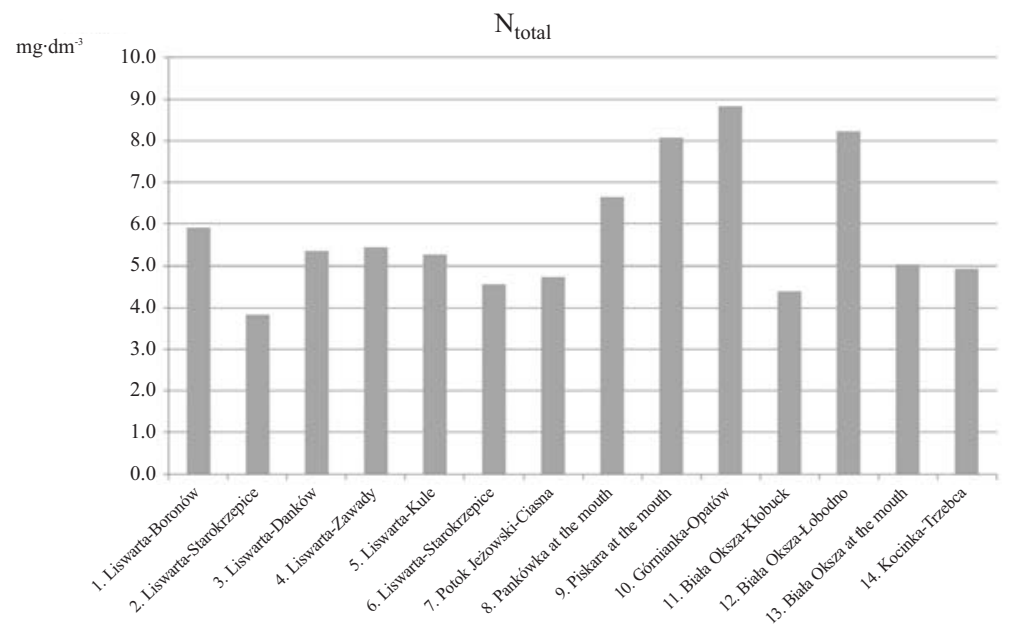

Fig. 7. The average concentration of total nitrogen at surface water monitoring sites from 2000-10. 


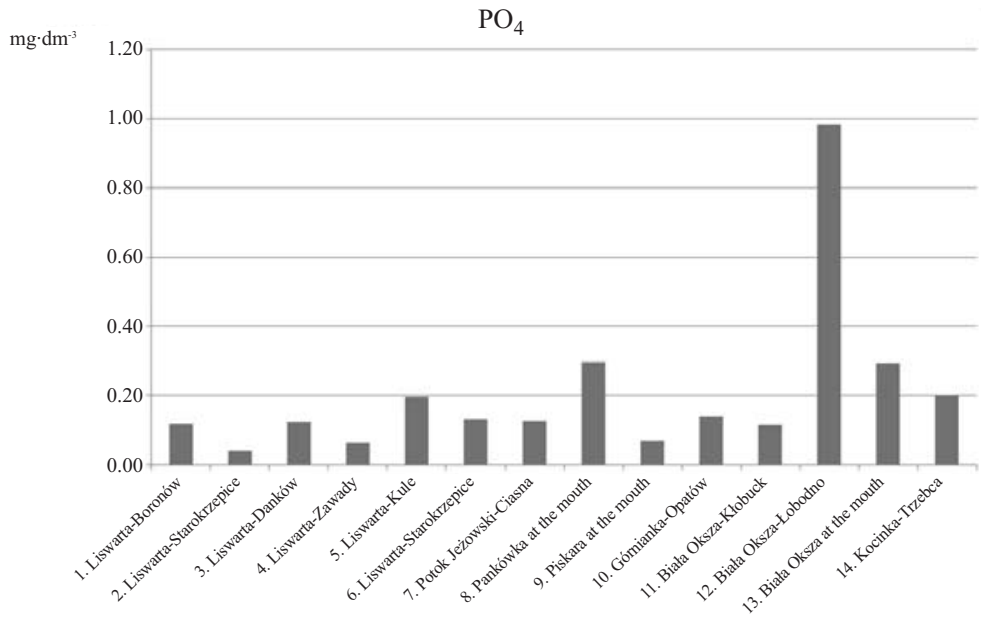

Fig. 8. The average concentration of $\mathrm{PO}_{4}^{3-}$ at surface water monitoring sites from 2000-10.

average concentration levels were $0.114 \mathrm{mg} \cdot \mathrm{dm}^{-3}$ and 0.293 $\mathrm{mg} \cdot \mathrm{dm}^{-3}$, respectively. The lowest average concentrations were collected from water at Starokrzepice on the Liswarta river $\left(0.040 \mathrm{mg} \cdot \mathrm{dm}^{-3}\right)$, Zawady on the Liswarta River $\left(0.064 \mathrm{mg} \cdot \mathrm{dm}^{-3}\right)$, and from the mouth of the Piskara River $\left(0.069 \mathrm{mg} \cdot \mathrm{dm}^{-3}\right)$. The phosphate concentrations that were recorded at the other sites on the Liswarta River were 0.117 $\mathrm{mg} \cdot \mathrm{dm}^{-3}$ (Boronów), $0.123 \mathrm{mg} \cdot \mathrm{dm}^{-3}$ (Danków), and 0.197 $\mathrm{mg} \cdot \mathrm{dm}^{-3}$ (Kule) (Fig. 8).

The highest average total phosphorus concentrations from 2000-10 were observed at Łobodno on the Biała Oksza River. At the mouth of the Biała Oksza River, the average total phosphorus concentration was $0.184 \mathrm{mg} \cdot \mathrm{dm}^{-3}$. At two sites (Ciasna on the Potok Jeżowski River and at Trzebca on the Kocinka River), the average total phosphorus concentration levels exceeded $0.180 \mathrm{mg} \cdot \mathrm{dm}^{-3}$. The average phosphorus concentrations were reported at the other sites and remained below $0.1 \mathrm{mg} \cdot \mathrm{dm}^{-3}$ (Fig. 9).

\section{Discussion}

Land use itself does not affect water quality. However, human activities on land use changes could influence the types and degree of pollution. Therefore, measuring the proportions of certain land use types in a watershed might enable us to predict water quality [33].

Agricultural land use predicts fewer water quality variables than built-up land use, which is the primary contributor to degraded water quality [33-35]. Nevertheless, builtup land use remains significantly related to most variables, which suggest that point source pollution also positively contributes to the nutrient content and organic matter in the river water [36].

Water from agricultural areas has 2- to 4.5-fold higher total nitrogen $(\mathrm{N})$ concentrations than water from semi-natural areas [37]. Runoff of biogenic elements into surface water from agricultural areas is largely dependent on the type and volume of agricultural activity as well as the vulnerability of soil to erosion along with its permeability. Soils of high use value, in combination with adequate cultivation technologies, offer considerable prospects for agriculture [6]. Leaching of $\mathrm{N}^{-\mathrm{NO}_{3}}$ from field crops into the aquatic environment may reach levels up to $40 \mathrm{~kg} \cdot \mathrm{ha}^{-1}$, depending on the level of fertilization; but in the case of grasslands the observed levels may be considerably lower. Water erosion and surface runoff are the major routes for phosphorus leaching from agricultural areas into water resources [6, 14, 38].

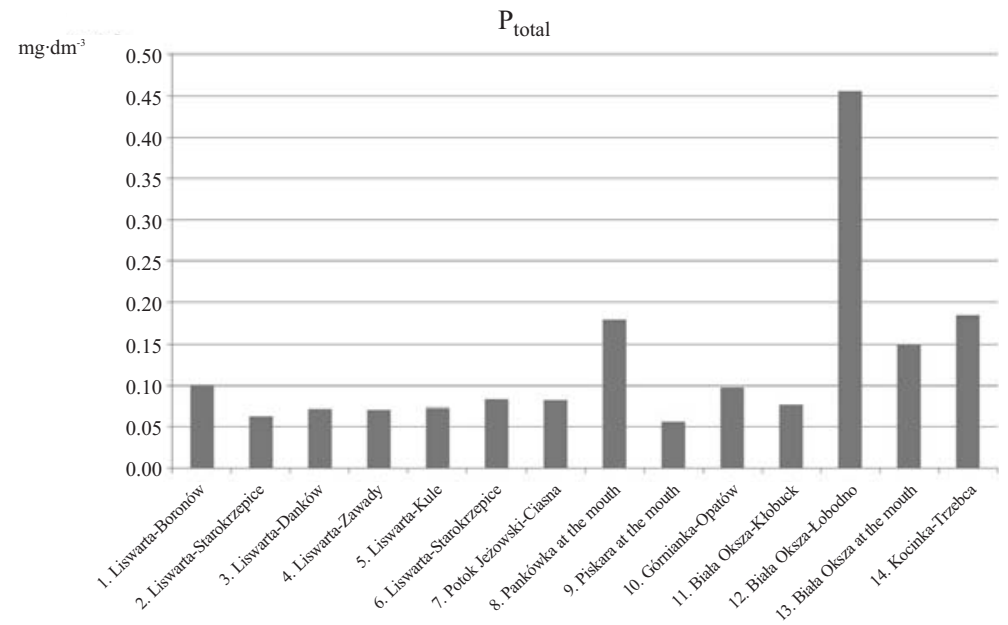

Fig. 9. The average concentration of total phosphorus at surface water monitoring sites from 2000-10. 
The waters of the Liswarta River and its tributaries can be regarded as eutrophicated or at an increased risk of eutrophication because nitrate concentrations have been reported at most of the sites, except Starokrzepice, and the levels exceed a limit of $10 \mathrm{mg} \cdot \mathrm{dm}^{-3} \mathrm{NO}_{3}^{2-}$. In the case of total nitrogen concentrations, the average annual limit of $5 \mathrm{mg}$ was exceeded at the following sites: Boronów, Danków, Kule - for the Liswarta River, Łobodno, the mouth of the Biała Oksza River, and the Górnianka, Piskara, and Bieszcza rivers. The maximum allowable phosphorus level $\left(0.25 \mathrm{mg} \cdot \mathrm{dm}^{-3}\right)$ was exceeded at only one site, the Lobodno (on the Biała Oksza River).

The optimal N:P concentration for algal growth is 7 . With ratios lower than 7, the growth of phytoplankton is limited by nitrogen [39]. If the value exceeds 60 , the growth of algae is constrained by phosphorus $[6,30]$. The N:P ratio observed for the Liswarta catchment ranges between 18 (Biała Oksza River - Łobodno) and 143 (the mouth of the Piskara River). A chemical barrier to the growth of algae (N:P values below 60) was not reported at the following sites: on the Biała Oksza River at Kłobuck (57), on the Biała Oksza River at Łobodno (18), on the Biała Oksza River at the mouth (33), on the Kocinka River at Trzebca (27), on the Pankówka River at the mouth (57), on the Potok Jeżowski River at Ciasna (54), and on the Bieszcza River at Krzepice (37). The maximum limits of 60 and 61 were reported on the Liswarta River at Boronów and Starokrzepice.

In the case of rivers where agricultural land covers more than $80 \%$ of the catchment area, that is the Piskara (86\%) and Górnianka ( $82 \%$ ) rivers, the average total nitrogen concentrations from $2000-10$ exceeded $8 \mathrm{mg} \cdot \mathrm{dm}^{-3}$. In catchments where agricultural land constitutes $70-80 \%$ of the entire catchment area, such as the Pankówka (70\%), Kocinka (71\%), and Bieszcza (79\%) rivers, the average total nitrogen levels ranged from $6.43 \mathrm{mg} \cdot \mathrm{dm}^{-3}$ (Bieszcza) to $4.93 \mathrm{mg} \cdot \mathrm{dm}^{-3}$ (Kocinka). In the case of the Biała Oksza River in Łobodno, high concentrations of nitrogen and phosphorus compounds were caused by municipal sewage. The Łobodno site is located below Kłobuck, which is the largest town in the Liswarta catchment. Significantly lower levels of ammonia, nitrites, nitrates, phosphates, and total phosphorus at the river's mouth indicate the self-cleaning capacity of the river. Some compounds have been sorbed by plants or diluted and dissolved.

\section{Conclusions}

Agricultural production constitutes a real risk to surface and groundwater quality. Inadequate farming practices, together with poor sanitary conditions on farmsteads, result in biogenic substances being leached into water resources. Studies carried out in the Liswarta catchment area indicated that high concentrations of nitrogen and phosphorus compounds in the surface water are closely connected to the land use pattern in the catchment basin. The surface water in the Liswarta catchment is characterized by high concentrations of biogenic compounds that occur in both predominantly agricultural catchments and in the Bieszcza catchment, where the largest town in the study area exists - Kłobuck. Increased concentrations of biogenic compounds in the Biała Oksza River result from municipal sewage discharges. Water in the Liswarta River, as well as in its tributaries, can be regarded as eutrophicated or at a high risk of eutrophication, particularly in the Kocinka, Pańkówka, Potok Jeżowski, Bieszcza, upper Liswarta, and Biała Oksza rivers.

Protecting water from biogenic contamination requires a new approach to fertilizer use as well as improvement in the sanitary condition of households to be achieved by, among other things, the installation of drainage systems in rural areas. It is also necessary to take a closer look at small watercourses draining into the Liswarta catchment. Recommendations include the protection of river valleys by stopping deforestation, preserving the natural riparian vegetation and reducing the volume of intensified agricultural activity or introducing so-called "precision farming."

\section{References}

1. WOLSKA L., POLKOWSKA Ż. Bacterial luminescence test screening of highly polluted areas in the Odra River. B. Environ. Contam. Tox., 67, 51, 2001.

2. PULIKOWSKI K., CZYŻYK F., PAWĘSKA K., STRZELCZYK M. The share of nitrate nitrogen in the total nitrogen content of the water flowing from the agricultural catchment area. Infrastruktura i ekologia terenów wiejskich. pp. 155, No. 3///2012 [In Polish].

3. SMOROŃ S. Phosphorus cycle in agriculture and the threat to water quality. Zeszyty Edukacyjne. Z. 1. Falenty. IMUZ, pp. 86, 1996 [In Polish].

4. FISCHER G., WINIWARTER W., ERMOLIEVA T., CAO G.-Y., QUI H., KLIMONT Z., WIBERG D., WAGNER F. Integrated modeling framework for assessment and mitigation of nitrogen pollution from agriculture: Concept and case study for China. Agriculture, Ecosystems \& Environment, 136, (1-2), 116, 2010.

5. POLKOWSKA Ż., GÓRECKI T., NAMIEŚNIK J. Determination of atmospheric pollutants in wet deposition. Environmental Reviews, 19, 185, 2011.

6. SMOROŃ S., KUŹNIAR A., KOWALCZYK A. The Loads of Chemical Components (NPK) in the Proszowice Plateau (the Given Example Being of the Szreniawa Catchment). Pol. J. Environ. Stud., 20, (4A), 312, 2011.

7. NEAL C., JARVIE H. P., WITHERS P. J.A., WHITTON B. A., NEAL M. The strategic significance of wastewater sources to pollutant phosphorus levels in English rivers and to environmental management for rural, agricultural and urban catchments. Sci. Total Environ., 408, 1485, 2010.

8. RODE M., THIEL E., FRANKO U., WENK G., HESSER F. Impact of selected agricultural management options on the reduction of nitrogen loads in three representative meso scale catchments in Central Germany. Sci. Total Environ, 407, 3459, 2009.

9. PIOTROWICZ R., KRASKA M., KLIMASZYK P., SZYPER H., JONIAK T. Vegetation Richness and Nutrient Loads in 16 Lakes of Drawieński National Park (Northern Poland). Pol. J. Environ. Stud., 15, (3), 467, 2006.

10. DUNALSKA J. Influence of Limited Water Flow in a Pipeline on the Nutrients Budget in a Lake Restored by Hypolimnetic Withdrawal Method. Pol. J. Environ. Stud. 11, (6), 631, 2002. 
11. JAROSIEWICZ A., WITEK Z. Seasonal Translocations of Nitrogen and Phosphorus in Two Lobelian Lakes in the Vicinity of Bytów, (West Pomeranian Lake District). Pol. J. Environ. Stud. 18, (5), 827, 2009.

12. ŻUREK A. The assessment of nitrate losses into groundwater on the base of measurements in small agricultural catchments. Biuletyn Państwowego Inst. Geol. 436, 589, 2009 [In Polish].

13. CZABAN S. [Ed.] Assessment of anthropogenic impacts on water bodies in agricultural catchment. Monografia, seria Współczesne Problemy Inżynierii Środowiska 15, 80, 2009.

14. SMORON $\mathrm{S}$. The threat of eutrophication of surface waters of loess upland region Małopolska. Woda-ŚrodowiskoObszary Wiejskie. 12, (1), 37, 181, 2012 [In Polish].

15. THORNTON G.J.P., DISE N.B. The influence of catchment characteristics, agricultural activities and atmospheric deposition on the chemistry of small streams in the English Lake District. Sci. Total Environ. 216, 63, 1998.

16. DURKOWSKI T., WORONIECKI T. Surface water quality in rural areas of Western Pomerania. Zesz. Probl. Post. Nauk Rol. 476, 365, 2001 [In Polish].

17. JARVIE H.P., WITHERS P.J.A., BOWES M.J., PALMERFELGATE E.J., HARPER D.M., WASIAK K., WASIAK P., HODGKINSON R.A., BATES A., STOATE C., NEAL M., WICKHAM H.D., HARMAN S.A., ARMSTRONG L.K. Streamwater phosphorus and nitrogen across a gradient in rural-agricultural land use intensity. Agriculture, Ecosystems and Environment, 135, 238, 2010.

18. ABSALON D., ŚLESAK B. The effects of changes in cadmium and lead air pollution on cancer incidence in children. Sci. Total Environ. 408, (20), 4420, 2010.

19. ABSALON D., ŚLESAK B. The importance of time of exposure to harmful anthropogenic factors as an element of cancer risk assessment in children. Ecotox. Environ. Safe. 74, (4), 967, 2011

20. DULIAS R., HIBSZER A. Silesia province: nature, economy, cultural heritage. Kubajak, Krzeszowice, pp. 224, 2004 [In Polish].

21. Evaluation of designated sensitive areas in Poland in pollution nitrogen compounds. Alterra Nauki Przyrodnicze i Uniwersytet i Ośrodek Badawczy Wageningen, 2007 [In Polish].

http://www.kzgw.gov.pl/files/file/Materialy_i_Informacje/ Dyrektywy_Unijne/Azotowa/Ocena_KE_OSN_PL.pdf.

22. ZIMNY L. Definitions and divisions of agricultural systems. Acta Agrophysica, 10, (2), 507, 2007 [In Polish].

23. POLKOWSKA Ż., TOBISZEWSKI M., GÓRECKI T., NAMIEŚNIK J. Pesticides in rain and roof runoff waters from an urban region. Urban Water Journal, 6, 441, 2009.

24. KONDRACKI J. Regional geography of Poland. Wydawnictwo Naukowe PWN, Warszawa, 2002 [In Polish].

25. GUZIK M. Nitrates in groundwater of the upper Liswarta river basin. Biuletyn Państwowego Inst. Geol. 432, 55, 2008 [In Polish].
26. RUBIN K., RUBIN H. Hydrogeological Map of Poland 1:5000 sheet Lubliniec 843 and explanations. Centr. Arch. Geol. Państw. Inst. Geol., Warszawa, 2000 [In Polish].

27. KOZIEŁ M. The use of Corine Land Cover 2000 database for analysis of landscape structure of selected protected areas in Poland. Classification of the landscape. Theory and practice. Problemy Ekologii Krajobrazu XX, 279, 2008 [In Polish].

28. CIOŁKOSZ A., BIELECKA E. Land cover in Poland. CORINE Land Cover database. Biblioteka Monitoringu Środowiska. Warszawa, pp. 76, 2005 [In Polish].

29. BIELECKA E., SZMAŃDA J. B., LUC M. Attempt to evaluate the differences in land cover based on a comprehensive of the multindicator analysis - the valley of the Vistula and the Oder, the case study. [In:] Myga-Piatek U. (Ed.). Doliny Rzeczne. Przyroda - krajobraz - człowiek. Prace Komisji Krajobrazu Kulturowego PTG, Sosnowiec, 41, 2007 [In Polish].

30. ILNICKI P. Polish agriculture and the environmental protection. AR Poznań, pp. 483, 2004 [In Polish].

31. SOSZKA H. Methodological problems related to the assessment of the degree of eutrophication of lakes for the purpose of determining nitrate vulnerable zones. Woda-SrodowiskoObszary Wiejskie. 9, (1), 25, 151, 2009 [In Polish].

32. Water Law Act, The Act of July 18, 2001. J. Law 2005 No. 239 Item 2019 as amended.

33. BU H., MENG W., ZHANG Y., WAN J. Relationships between land use patterns and water quality in the Taizi River basin, China. Ecol. Indic. 41, 187, 2014.

34. BAKER A. Land use and water quality. Hydrol. Process. 17, 2499, 2003.

35. SCHOONOVER J. E., LOCKABY B. G. Land cover impacts on stream nutrients and fecal coliform in the lover Piedmont of West Georgia. J. Hydrol. 331, 371, 2006.

36. KAZI T. G., ARAIN M. B., JAMALI M. K., JALBANI N., AFRIDI H. I., SARFAZ R. A., BAIG J. A., SHAH, A. Q. Assessment of water quality of polluted lake using multivariate statistical techniques: a case study. Ecotox. Environ. Safe. 72, 301, 2009.

37. KOC J., CIEĆKO C., JANICKA R., ROCHWERGER A. Factors affecting the level of mineral nitrogen in the waters of the agricultural area. Zeszyty Problemowe Postępów Nauk Rolniczych 440, 175, 1996 [In Polish].

38. SAPEK A. Diffusion of phosphorus into the environment mechanisms and consequences. In: Goals and ways to reduce the dispersion of nutrients from agriculture to the environment. Zeszyty Edukacyjne No. 7, 309, 2002 [In Polish].

39. KAJAK Z. The impact of agriculture on the eutrophication of water reservoirs. [In:] Skład chemiczny wód glebowych gruntowych i powierzchniowych w warunkach intensywnej produkcji rolniczej. Scientific Symposium. 11-12. 06. 1979. Part II. Puławy. IUNG. 94, 1984. 